\title{
O LIXO, O ESGOTO NA BAÍA DE GUANABARA E OS PROGRAMAS DE DESPOLUIÇÃO: A MÍDIA VERSUS OS DADOS
}

\author{
Luis Gabriel Rodrigues Souza ${ }^{1}$
}

\author{
Antonio Carlos de Miranda ${ }^{2}$
}

Herika Bastos de Medeiros ${ }^{3}$

\begin{abstract}
RESUMO
A Baía de Guanabara, no Rio de Janeiro, palco do descaso das autoridades governamentais, que anos após anos criam planos de despoluição, que não se concretizam. Este artigo traz à tona a discussão desse impacto ambiental e os efeitos dos poluentes ao meio ambiente. Ao mesmo tempo em que os dados de contaminação eram divulgados, os governos, em contrapartida, apresentam na mídia planos para o futuro que não são cumpridos. Nesse sentido se faz imprescindível uma gestão ambiental comprometida com a sociedade, visando investimentos que realmente consigam apresentar retorno de melhoria de qualidade das águas da Baía.
\end{abstract}

PALAVRAS-CHAVE: poluição das águas por bactérias coliformes, micro-organismos e resíduos sólidos.

\section{GARBAGE, THE SEWAGE IN GUANABARA BAY AND REMEDIATION PROGRAMS: THE VERSUS MEDIA DATA.}

\begin{abstract}
The problem is that the Guanabara Bay, in Rio de Janeiro who year after year create plans and new plans remediation, who do not materialize. As a result of this environmental impact of polluting effects are disastrous for the environment. At the same time, in which the current data of contamination are disclosed the governments on the other hand present in media plans for the future, which are not accomplished. In this sense it is essential a society committed to environmental management aimed at investments that actually unable to submit feedback to improve water quality of the Bay.
\end{abstract}

KEY-WORDS: water pollution by coliform bacteria, micro-organisms and solid waste.

\footnotetext{
${ }^{1}$ Mestre em Ensino da Saúde e do Ambiente (UNIPLI), Prof. da Rede Municipal de São Gonçalo e da Rede Estadual do RJ

${ }^{2}$ Doutor (UNICAMP); Prof. do Programa de Pós-graduação UNIAN; mirantam@ig.com.br

${ }^{3}$ Mestre em Ensino da Saúde e do Ambiente (UNIPLI), Prof. da Rede Municipal de São Gonçalo e Rio de Janeiro; herikabastos@yahoo.com.br
} 


\section{BASURA, EL ALCANTARILLADO EN BAHÍA DE GUANABARA Y LOS PROGRAMAS DE RECUPERACIÓN: EL VERSUS LOS MEDIOS DE DATOS.}

\section{RESUMEN}

Bahía da Guanabara, en Rio de Janeiro, en este artículo se plantea la discusión sobre el impacto ambiental y los efectos de los contaminantes en el medio ambiente. Al mismo tiempo, los datos fueron a conocer la contaminación, los gobiernos sin embargos, apresentam em el planes de medio para el futuro que no se cumplen. Por más d cien años la Bahia de Guanabara está mostrando signos de degradación.

En este sentido, es esencial una gestión ambiental comprometida con la sociedad dirigindo a las inversiones que en realidad apresentar retorno y mejorar la calidad del agua de la bahía.

PALABRAS-CLAVE: contaminación del agua por bacterias coliformes, microorganismos y residuos sólidos

\section{1- INTRODUÇÃO}

Com uma área total de $346 \mathrm{~km}^{2}$, incluindo $59 \mathrm{~km}^{2}$ de ilhas e uma bacia hidrográfica tributária de $4000 \mathrm{~km}^{2}$ com 35 rios, a Baía de Guanabara, no Rio de Janeiro, é a segunda maior em extensão do litoral brasileiro. Entretanto, a cada dia aumenta a contaminação de suas águas, com lixo, dejetos e esgoto in natura.

Nesse contexto, vale lembrar que o Rio de Janeiro será palco das competições aquáticas durante as Olimpíadas de 2016. Através do Programa de Despoluição da Baía de Guanabara - PDBG, o Governo do Estado e a Prefeitura do Município do Rio de janeiro informaram à mídia, obras com investimento de cerca de $\mathrm{R} \$ 1,5$ bilhões para o saneamento básico na região. Atualmente, apresentaram um novo Programa de Saneamento Ambiental dos Municípios do Entorno da Baía de Guanabara - PSAM, que prevê mais gastos e com valores que devem ser superiores de $R$ \$ 1,13 bilhão em obras.

O tema é relevante, pois essa contaminação pode provocar danos à saúde da população e ao meio ambiente. Doenças graves podem ser transmitidas pela água contaminada com dejetos, lixo doméstico e resíduos industriais.

Por outro lado, a mídia transformou-se, em contrapartida, em um espaço importante de denúncia da população, em relação às agruras e aos danos ambientais 
à Baía de Guanabara e, por certo, aos fracassos das metas desses 'Planos' governamentais. Cabe lembrar que o governo não conseguiu através de seu primeiro programa (PDBG) alcançar as metas propostas, mesmo com os altos valores investidos. A seguir, criou-se outro programa (PSAM), em andamento, também de alto custo, cujo objetivo era despoluir $80 \%$ da Baía de Guanabara até 2016, compromisso assumido com o Comitê Olímpico Internacional. Entretanto, o governo percebeu que essa meta também não vai ser alcançada, prorrogada para 2018.

\section{2- DESENVOLVIMENTO}

\section{1- Breve Histórico}

Os primeiros sinais da gravidade da contaminação da Baía de Guanabara surgiram principalmente, na década de 1960, fruto do processo de ocupação das suas margens e dos rios que compõem a sua bacia hidrográfica. Na verdade, a história do processo de urbanização e as diversas reformas urbanas da cidade do Rio de Janeiro contribuíram para essa contaminação. Cabe destacar que esses processos urbanos com frequência foram (ou são) discriminatórios, pois afasta das áreas nobres ou mais valorizadas da cidade a população mais pobre, conduzindo-a para a periferia, ou obrigando-a a viver nas encostas dos morros ou nas margens dos rios, agravando as suas próprias condições de saneamento e reduzindo a drenagem das águas das chuvas, como apontam Rodrigues \& Miranda (2014). "Portanto, essas pessoas serão as vítimas também das enchentes e dos deslizamentos. Assim, todo esse processo representa uma injustiça social e ambiental". No século XIX, a contaminação da Baía de Guanabara já era identificada pelo Engenheiro André Rebouças que afirmava que a empresa de saneamento da época "convertera a Baía de Guanabara numa imensa cloaca” (1888, p. 49). Isso ocorria porque a 'estação de tratamento' eram tanques de precipitação e os efluentes eram despejados diretamente na Baía de Guanabara.

O objetivo deste estudo é demonstrar que diante do grave cenário atual, em que dezoito (18) mil litros de esgoto deságuam a cada segundo na Baía de 
Guanabara, e, desse total, dez (10) mil, in natura, os programas ('Planos') governamentais demonstraram serem ineficientes em relação às metas que se propuseram alcançar. Nesse sentido, este estudo representa uma pesquisa qualitativa de caráter descritivo, documental e iconográfico. Utilizou-se, para isso, artigos acadêmicos, documentos oficiais, sites, diversas mídias, principalmente fotos. Analisou-se, entre outros aspectos, a forma como esses programas, 'Planos', são divulgados na mídia. Já que imediatamente se transformam em 'soluções', pelo formato em que são apresentados, com, claro, 'metas futuras ambiciosas'. Quando começam a surgir evidências de que elas não serão alcançadas: um novo 'Plano' apresenta-se.

Todavia, o que tem sido demonstrado nesses programas é a ausência de diversas ações que conjuguem um (alto) investimento, planejamento, gestão adequada, continuidade, monitoramento, fiscalização, controle e, ainda, parcerias com Institutos de Pesquisa e Universidades. Além disso, é fundamental conscientizar aos moradores que vivem em áreas degradadas e sem saneamento dos danos que são provocados ao meio ambiente e exigir políticas públicas e investimentos. $\mathrm{Na}$ verdade, com isso, evitando que esses moradores sejam as maiores vítimas desses danos ambientais. Nesse sentido, é fundamental enfatizar a importância da Educação Ambiental, neste processo de conscientização.

Vale lembrar o Programa de Despoluição da Baía de Guanabara (PDBG) que foi apresentado na Eco+92, começou a ser executado de forma lenta em 1994 e foi interrompido algumas vezes. Vigorou até 2006, envolvendo um conjunto de obras e atividades multidisciplinares com aperfeiçoamento humano e técnico dos órgãos operadores, visando reduzir os índices de contaminação. Entretanto, essa tentativa e as suas melhorias não mudaram o cenário dessa crescente contaminação, que continuou se agravando. É importante destacar que, nesse período, os estudos acadêmicos e técnicos relativos à contaminação da Baía da Guanabara já afirmavam que a principal fonte de poluição era a ausência de tratamento adequado do esgoto doméstico e industrial dos quinze municípios que ficam no seu entorno. 
Um novo Programa é apresentado pela Secretaria de Estado do Ambiente: o PSAM (Programa de Saneamento Ambiental dos Municípios do Entorno da Baía de Guanabara), em que o seu Projeto Básico de Engenharia foi concluído em dezembro de 2012, e está em andamento, que prevê gastos superiores de $R \$ 1,13$ bilhão em obras de esgotamento sanitário e em projetos de saneamento dos 15 municípios do entorno da Baía de Guanabara, a saber, Belford Roxo, Cachoeiras de Macacu, Duque de Caxias, Guapimirim, Itaboraí, Magé, Mesquita, Nilópolis, Niterói, Nova Iguaçu, Rio Bonito, Rio de Janeiro, São João de Meriti, São Gonçalo e Tanguá.

\begin{abstract}
O Projeto Básico de Engenharia desse sistema foi concluído em dezembro de 2012, sendo aprovado pela área técnica da Cedae. Em 18 de dezembro, foi realizada audiência pública para apresentação do projeto e, em janeiro de 2013, iniciado o processo de contratação da obra, na modalidade de licitação internacional pelas regras do Banco Interamericano de Desenvolvimento (BID); com a publicação do Edital de Pré-Qualificação das empresas construtoras interessadas. As obras se iniciaram em julho de 2014 (RJ.GOV,2014).
\end{abstract}

Também nesse novo programa estão ações diferenciadas que incluem:

a) Saneamento;

b) Colocação de cinco Unidades de Tratamento de Rio (UTRs). Para melhor compreensão a UTR utiliza um método físico-químico para retirar cerca de $80 \%$ da carga orgânica das águas poluídas. Já existem UTRs no Rio Carioca (no Aterro do Flamengo) e no Piscinão de Ramos.

Figura 1 e 2- UTR'S

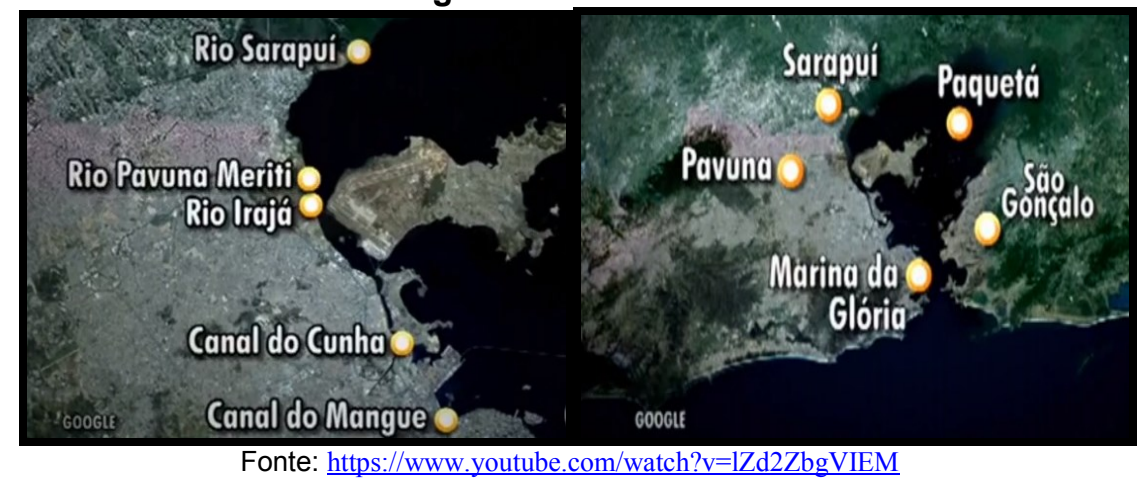


c) Fechamento de todos os lixões em torno da Baía de Guanabara. Pois com essa ação, o chorume que deixou de ir para a água corresponde ao volume de "um Maracanã por semana" (SEA).

d) Recolhimento do lixo flutuante nas águas, a partir dos primeiros dias de 2014, com os ecobarcos, dez unidades previstas até o fim do ano.

Figura 3- Ecobarreira do Canal do Cunha

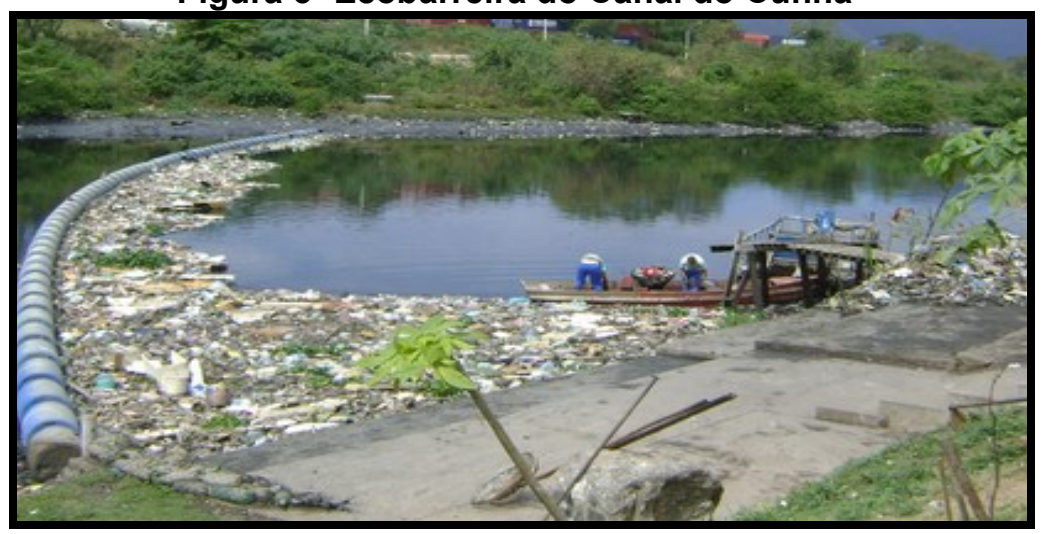

Fonte: Guanabara Limpa.

Entretanto, mesmo com o segundo Plano de despoluição em andamento, as imagens e os dados pela mídia indicam um alto grau de poluição na Baía de Guanabara e dos rios de sua bacia hidrográfica. "Em saneamento, o Rio ainda está com os pés no século XIX" - destaca a engenheira química Dora Negreiro (BVRIO, 2014).

Lembremos que a principal fonte de poluição é ausência de saneamento de municípios que ficam no entorno da Baía, que despejam diretamente o esgoto e os efluentes industriais na própria baía ou nos rios da sua bacia hidrográfica. A tabela abaixo demonstra o baixo atendimento de saneamento à população urbana. 
Tabela 1- Atendimento de saneamento à população urbana

\begin{tabular}{|l|l|c|}
\hline \multicolumn{1}{|c|}{ Município } & Nível de Tratamento & $\begin{array}{c}\text { \% da população } \\
\text { urbana atendida }\end{array}$ \\
\hline Belford Roxo & Secundário & 18,2 \\
\hline Duque de Caxias & Secundário & 2,2 \\
\hline Itaborái & Secundário & 3,8 \\
\hline Mesquita & Secundário & 3,3 \\
\hline Nilópolis & Primário & 2,5 \\
\hline Niterói & Emissário submarino & 57,5 \\
& Secundário & 23,4 \\
& Terciário & 8,8 \\
\hline Nova Iguaçu & Secundário & 2,7 \\
\hline Rio de Janeiro & Secundário & 21,2 \\
& Emissário submarino & 34,9 \\
\hline São Gonçalo & Primário & 0,1 \\
& Secundário & 7,5 \\
\hline São João de Meriti & Secundário & 5,3 \\
\hline Tanguá & Primário & 9,8 \\
\hline
\end{tabular}

Fonte: ICMS- Ecológico (Ano de Referência: 2010) - SEA, 2011.

A região da Bacia Hidrográfica da Baía de Guanabara é caracterizada pela inadequada gestão dos esgotos sanitários e dos resíduos sólidos urbanos. Os rios das bacias que atravessam as áreas mais densamente povoadas funcionam como 'esgotos a céu aberto' e também recebem grandes contribuições de despejos industriais (SEA, 2011).

Os dados relativos ao Brasil, representados pelos gráfico 1 e 2, também demonstram valores relativamente baixos do esgotamento sanitário e de outros tipos de serviços de abastecimento à população. 


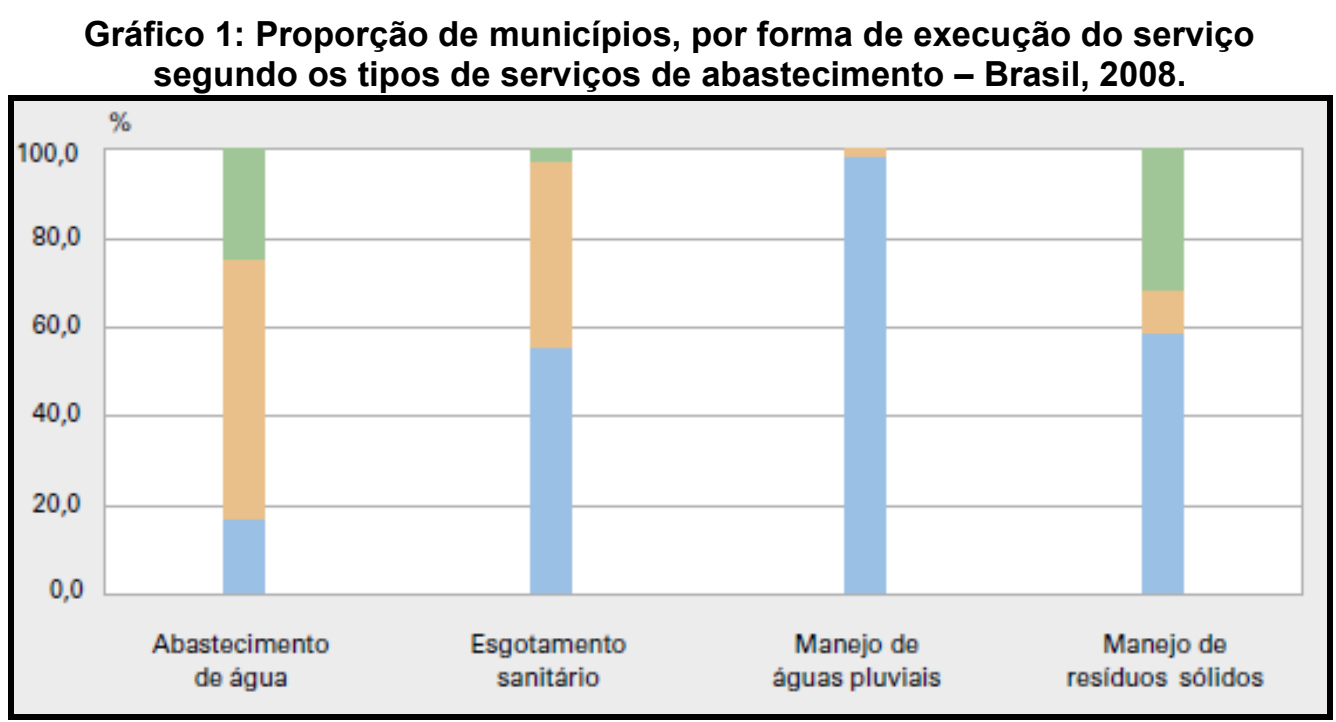

Fonte: IBGE, 2008

Gráfico 2- Percentual de municípios com ampliações nos serviços de esgoto sanitário.

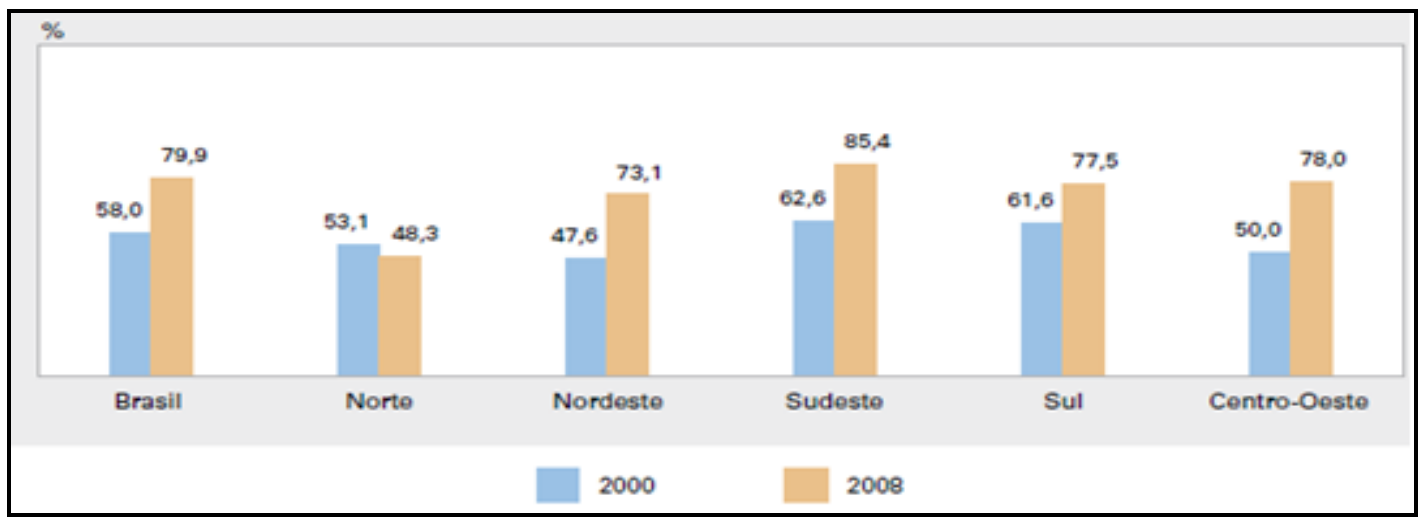

Fonte: IBGE, 2008.

Sobre a Poluição da Baía, Paulo Canedo, membro da Associação Brasileira de Recursos Hídricos (ABRH), e da (Coppe-UFRJ), ressaltou:

Quando a gente colocar esse dois planos [esgoto e lixo] a níveis, eu diria, nem aceitáveis, mas para não ficar com vergonha, a gente começa a falar do terceiro, a gente vai falar também do $\mathrm{pH}$ [da água], (...). Como falar de mais fatores se a gente não consegue resolver o esgoto e o lixo? (AGÊNCIA BRASIL, 2014). 
Para Canedo, apenas a coleta do esgoto não resolve o problema da contaminação. Para isso, é necessário coletar e tratar o esgoto adequadamente, para que os resíduos líquidos que sobram da estação de tratamento sejam neutralizados ao serem jogados na baía. Enquanto a parte sólida, que são os rejeitos das estações de tratamento, o 'lodo', seja levado aos aterros sanitários.

Ainda sobre a melhoria na qualidade da água, para a ministra do Meio Ambiente, Izabella Teixeira afirma, "se a questão entrar na agenda de todos os governos o problema só será resolvido pelos próximos 20 anos, com a cobrança da sociedade para que isso ocorra". (AGÊNCIA BRASIL, 2014)

\title{
2.2. Impurezas nas Águas
}

A mídia aponta a gravidade dos problemas ambientais das águas no município do Rio de Janeiro. Esse destaque ocorre principalmente em razão de dois grandes eventos: Copa do Mundo e Jogos Olímpicos. Por sua vez, a literatura acadêmica e técnica assinalam como principais fontes de poluição das águas no município do Rio de Janeiro, em sua maioria, os esgotos domésticos, as águas pluviais e os esgotos industriais, com a contaminação química.

A água devido as suas propriedades de solvente e a sua capacidade de transportar partículas incorpora a si diversas impurezas, as quais definem a qualidade da água.

\begin{abstract}
A poluição química nas águas pode ser causada por substâncias biodegradáveis ou substâncias persistentes. As biodegradáveis são decompostas por bactérias, enquanto as persistentes não se degradam facilmente e podem levar à contaminação da cadeia alimentar (MIRANDA, GOMES, SILVA, 2006, p: 49).
\end{abstract}

Vale assinalar que as impurezas encontradas na água podem ser definidas pelas suas características físicas, químicas e biológicas. Alguns parâmetros associados à sua forma física predominante e de maior importância relacionados ao lançamento de esgotos nos rios e mares estão destacados na tabela abaixo em negrito. 
Tabela 2. Tabela de parâmetros da Impureza do lançamento de esgoto

\begin{tabular}{|c|c|c|c|c|}
\hline Característica & Parâmetro & $\begin{array}{l}\text { Sólidos } \\
\text { suspensos }\end{array}$ & $\begin{array}{l}\text { Gases } \\
\text { dissolvidos }\end{array}$ & $\begin{array}{l}\text { Sólidos } \\
\text { dissolvidos }\end{array}$ \\
\hline & Cor & & $\mathrm{x}$ & \\
\hline \multirow[t]{6}{*}{ Física } & Turbidez & $x$ & & \\
\hline & Sabor e odor & $x$ & $x$ & $x$ \\
\hline & $\mathrm{pH}$ & & $\mathrm{x}$ & $\mathrm{x}$ \\
\hline & Alcalinidade, dureza e cloretos & & $x$ & \\
\hline & Acidez & & $x$ & $x$ \\
\hline & Ferro e manganês & $x$ & $x$ & \\
\hline \multirow{6}{*}{ Química } & Nitrogênio & $\mathbf{x}$ & $\mathbf{x}$ & \\
\hline & Fósforo & $\mathbf{x}$ & $\mathbf{x}$ & \\
\hline & Oxigênio dissolvido & & & $x$ \\
\hline & Matéria orgânica (DQO e DBO) & $\mathbf{x}$ & $\mathbf{x}$ & \\
\hline & Metais & $x$ & $x$ & \\
\hline & Micropoluentes orgânicos & & $x$ & \\
\hline the & Organismos indicadores (coliformes) & $\mathbf{x}$ & & \\
\hline \multirow[t]{2}{*}{ Biológica } & Algas & $x$ & & \\
\hline & Bactérias & $x$ & & \\
\hline
\end{tabular}

Fonte: Von Sperling, 2005, p.452

Segundo o autor, as fontes de poluição podem ter origem natural ou ser resultado das atividades humanas. As principais fontes de poluição das águas são expostas a seguir: a) Esgotos domésticos; b) Esgotos industriais; c) Resíduos sólidos; d) Carreamento de partículas do solo e Percolação do chorume dos depósitos de lixo.

Para se obter condições sanitárias adequadas, não basta que o esgoto seja adequadamente coletado por meio de uma rede geral. É necessário que também seja tratado, caso contrário, recursos hídricos ficarão poluído e haverá proliferação de doenças, como a diarreia, devido à contaminação da água por coliformes fecais, causando prejuízo à saúde da população e o aumento da mortalidade infantil (IBGE, 2008, p:45).

Vimos que a poluição das águas é originada de diferentes fontes e que trazem consequências negativas para o meio ambiente e para a qualidade de vida das pessoas. Para Von Sperling, o impacto da poluição proveniente de uma dessas fontes depende das especificidades do despejo, além das características do corpo d'água receptor, tais como, por exemplo, a eutrofrização dos corpos d'água, quando a população de algas pode alcançar valores bastante elevados, e poderão atingir superpopulações, que tem como consequência, mau odor, mortandades de peixes e problemas de toxicidade. Além disso, o assoreamento provocado pela entrada na água de resíduos sólidos impactantes. 


\title{
2.3. Novo Programa de Despoluição da Baía e a Mídia.
}

Apesar de mais um plano em ação com objetivo de reduzir o impacto ambiental da Baía da Guanabara, o quadro atual, praticamente não foi modificado. Ainda hoje é possível ver línguas negras, amarelas e verdes que contaminam as águas causadas por ressaca, chuvas fortes, e proliferação de microorganismos, essas manchas denunciam também o despejo de esgoto.

Diante da continuidade do descaso das autoridades, em um bairro de classe média e alta (Barra da Tijuca), em 2012, um grupo de 12 mil moradores conseguiu na justiça o direito de depositar em juízo o pagamento das altas contas da Cedae (Companhia Estadual de Águas e Esgotos-RJ).

\begin{abstract}
Liminar - Os moradores do Jardim Oceânico e do Tijucamar, regiões da Barra da Tijuca, ganharam ontem o direito de depositar em juízo o pagamento de suas contas de água e esgoto até o fim do julgamento de uma ação que movem contra a Cedae. A decisão foi do desembargador da $18^{\mathrm{a}}$ Câmara do Tribunal de Justiça, Roberto de Abreu, que negou o recurso da companhia e manteve a liminar favorável aos moradores expedida em junho. Metade dos 25 mil consumidores das duas regiões já está sendo beneficiada pela ação e os demais também podem se agregar ao processo. Outras associações de moradores da Barra e Jacarepaguá podem se juntar à ação. A liminar foi mantida porque a região não tem rede de saneamento básico (ALERJ, 2012).
\end{abstract}

Nesse contexto, via mídia, propagou-se durante vários anos o compromisso assumido com o Comitê Olímpico Internacional, desde o início de implantação do programa, a meta do governo do Estado do Rio de Janeiro de despoluir 80\% da Baía de Guanabara até 2016. Entretanto, o governo percebeu que essa meta não vai ser alcançada. Recentemente, em nota divulgada pelo Jornal O DIA, a data foi prorrogada.

"A nova previsão é atingir a meta de $80 \%$ da população fluminense com acesso a serviços de saneamento básico em 2018 - o esgoto doméstico é a principal fonte de poluição da baía”. (Sandro Vox/Agência O Dia/Estadão, 01/jul/2014). 
Observou-se que as opiniões sobre a contaminação da Baia da Guanabara são divergentes em vários setores da sociedade, apesar das notícias positivas divulgadas na mídia pelo governo em relação ao segundo Programa (PSAM). Todavia, a proposta de sua meta (serviço de saneamento básico para $80 \%$ da população) está distante dos recentes dados: "Em 2013 a coleta de esgoto chegou a 40\%" (AGÊNCIA BRASIL, 2014).

Com a proximidade dos Jogos, a organização carioca do evento informou que foram feitos testes em amostras de água coletadas e todos os resultados garantiram que o local é seguro para a saúde dos competidores.

Ainda segundo a organização carioca o diretor de esportes do Comitê Organizador do Rio-2016, explicou que: “(...) até o final do ano passado, tinham três eco-barco, hoje são dez. E mais de 12 a 14 barcos realizando outras ações para reter os lixos flutuantes, caso dos sacos plásticos".

Entretanto o depoimento que gerou desconfiança e polêmica: "Temos focos nas cinco áreas de competição, para não ter lixo flutuante nessas áreas, temos que dar as melhores condições de performance para os atletas (ESPN, 2014).

Cabe uma questão: e o restante da Baía?

Para melhor entender a declaração do gestor, o Evento esportivo abrangerá apenas cinco raias de disputa. São essas áreas que aparentemente serão atendidas.

"Pão de Açúcar, Escola Naval, Ponte, Copacabana e Niterói e as dez classes olímpicas da água: Masculino: 49er, Laser, 470 M, RS:X M, Finn. Feminino: 49er FX, Laser radial, 470 W, RS:X W" (Sandro Vox/Agência O Dia/Estadão, 01/07/2014).

Por outro lado, o uso dos ecobarcos e barreiras tem pequeno impacto no programa de despoluição permanente da Baía de Guanabara. Em relação às declarações ambíguas de gestores, outra questão se apresenta: Será que o segundo Plano de despoluição também não está conseguindo apresentar resultados positivos?

Depoimentos e imagens na mídia demonstram um cenário diferente daqueles divulgados pelas autoridades do município em relação às ações de descontaminação da baía. Vejamos a seguir: 
a) O atleta brasileiro Ricardo Winicki, de 34 anos, quarto colocado na Olimpíada em Atenas 2004, criticou, em seu site, as condições do mar no Rio de Janeiro. E rebateu as declarações anteriores de gestores da prefeitura afirmando que as condições da Baía eram adequadas e seguras para a competição.

b) Winicki, afirmou na internet este ano: "No treino e final da segunda regata, um saco plástico prendeu no meu barco e tive que parar três vezes para tentar tirar e isso acaba atrapalhando todo mundo e outros velejadores também tiveram problemas com o lixo flutuante na água”. E completou: Tem esgoto sendo despejado no entorno da Marina da Glória, onde os barcos saem (ESPN; UOL, 2014). O australiano Mathew Belcher, medalha de ouro na Olimpíada de Londres-2012, deixou claro recentemente ao jornal O DIA, que a situação da área de competição gerava preocupação.

c) Em janeiro deste ano (2014), a iatista brasileira Martine Grael encontrou um monitor de TV flutuando na Baía, e até postou foto em uma rede social na internet. Outros atletas relatam em seus sites que também já se depararam com animais mortos na Baía, como gato, rato (ESPN; UOL, 2014).

Figura 4- Lixo e animais mortos na Baía de Guanabara.

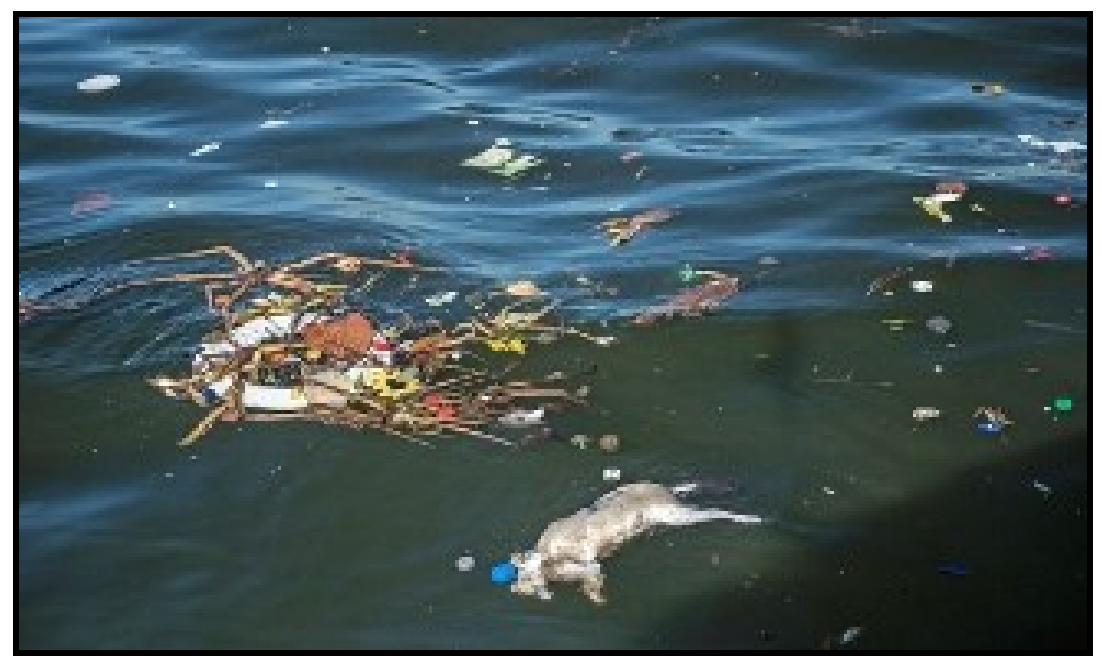

Fonte: O Dia/Estadão, 2014. 
Figura 5. Lixo se acumula na llha do Fundão-Baia de Guanabara

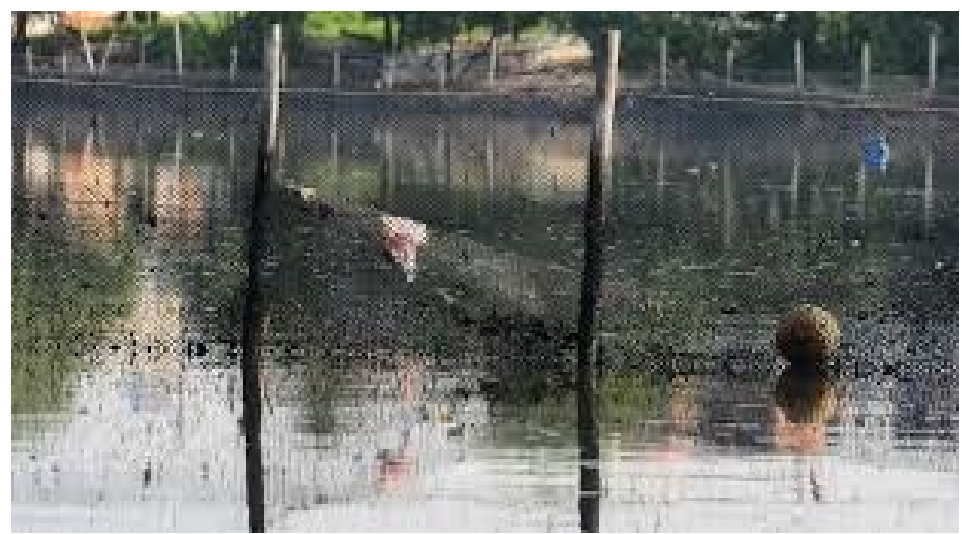

Fonte: Custodio Coimbra/Agência O Globo/ Notícias UOL, 21/05/2014 - Baía de Guanabara, RJ.

Figura 6. Imagem aérea mostra mancha escura na Lagoa da Tijuca

Fonte: Custodio Coimbra/Agência O Globo, 03/06/2014 - Barra da Tijuca, Rio de Janeiro

\section{Considerações Finais.}

O Governo Estadual pretendia deixar como legado (era afirmado na mídia) após os eventos 'Copa do Mundo' e 'Jogos Olímpicos', metas de saneamento, de tratamento e de limpeza, visando à despoluição da Baia da Guanabara. A 'Copa' já terminou e o planejado e as metas não foram alcançadas. Com os 'Jogos', porém o prazo foi prorrogado para 2018. Já o discurso em vigor foi alterado para "uma solução emergencial" com a retirada do lixo flutuante. 
O Governo do Estado do Rio de Janeiro assumiu um compromisso com o Comitê Olímpico Internacional (COI) de que até a realização dos jogos no país em 2016, oitenta por cento (80\%) do esgoto despejado na Baía de Guanabara seria tratado. Cabe lembrar que pelos dados da organização do Comitê Rio-2016, agora em 2014, apenas 49,5\% do esgoto despejado diariamente nas águas da Baia da Guanabara são tratados. Portanto, a partir desse dado atual e levando em conta que ele deverá ser somado, durante esse prazo, ao crescimento do despejo provocado pelo aumento da ocupação populacional nas áreas no entorno da Baía, que não possuem saneamento básico, faz com que essa meta dificilmente seja cumprida.

É importante assinalar que os dados apontam que a coleta de esgoto chegou a $40 \%$, em 2013. Enquanto que há sete anos, apenas $12 \%$ da população eram atendidas. Isso reforçava a dificuldade de alcançar essa meta de $80 \%$, em 2016, previsão anterior, e também a atual, em 2018. Por outro lado, o uso dos ecobarcos e barreiras tem pequeno impacto no programa de despoluição permanente da Baía de Guanabara. Nesse caso, apenas as obras de saneamento, coleta de lixo e de tratamento de esgoto representariam a solução. Para que não provoquem danos à saúde e ao ambiente, os resíduos sólidos e os dejetos gerados precisam ser coletados, transportados, tratados e dispostos adequadamente. Para isso, tornar-se fundamental a determinação e o levantamento de dados reais das cargas de poluentes, como também dos efeitos da sua afluência nos corpos receptores, e um planejamento e estimativas de seu crescimento futuro.

\section{REFERÊNCIAS}

AGÊNCIA BRASIL. Disponível em: http://agenciabrasil.ebc.com.br. Acesso em 31/7/2014.

ALERJ. Disponível em: http://www.alerj.rj.gov.brl. Acesso em 2012.

BITTENCOURT, Ana Lúcis Costa; SILVA, Marcelo Machado; BRASIL, Marconi Canuto; OLIVEIRA, Maria de Lourdes. Auditoria operacional no Programa de Despoluição da Baía de Guanabara. Rio de Janeiro, 2006.

BVRIO. Disponível em: http://www.bvrio.org/site/images/publicacoes/bvrio-funbio. Acesso em 2014.

IBGE. Pesquisa Nacional de Saneamento Básico. Rio de Janeiro, 2008. 
CANEDO, Paulo, Professor, Associação Brasileira de Recursos Hídricos (ABRH), Disponível em: http://agenciabrasil.ebc.com.br. Acesso em: 31/7/2014.

COIMBRA, Custodio. Fotos atuais da Poluição na Baía da Guanabara. Agência O Globo, jun.2014.

ESPN. Disponível em: http://espn.uol.com.br/noticia/430001. Acesso em 04/08/2014.

ESPN/UOL. Disponível em: http://espn.uol.com.br/noticia/429913. Acesso em 03/08/2014.

GUANABARA LIMPA. Saneamento Ambiental da Baía de Guanabara. Disponível em: http://www.guanabaralimpa.eco.br/pagina-divisoes.asp?divisao=1. Acesso em 2014.

MIRANDA, Antonio Carlos; GOMES, Haroldo Pereira; SILVA, Marcia Oliveira. Recursos Hídricos. São Paulo, All Print, 2008.

RAMOS, Marilene Ramos, Poluição na Baia da Guanabara. Inea. Disponível em: http://agenciabrasil.ebc.com.br. Acesso em 31/7/2014.

TEIXEIRA, Izabella. Melhoria na qualidade da água poluída, Disponível em: http://agenciabrasil.ebc.com.br. Acesso em 31/7/2014.

REBOUÇAS, André Pinto. Esgoto do Rio de Janeiro. Revista de Engenharia, p.49, 1888.

RJ.GOV. Disponível em: (http://www.ri.gov.br/web/sea/exibeconteudo?article-id=1455729. Acesso em 2014.

RODRIGUES, Marinéa; MIRANDA, Antonio Carlos de. História ambiental: o processo de saneamento da cidade do Rio de Janeiro. Revista Práxis - jun 2014.

UOL. Disponível em: http://noticias.uol.com.br/meio-ambiente/album/2014/05/21/poluicao-na-baia-deguanabara.htm?mobile. Acesso em 2014.

VON SERLING, M. Introdução à qualidade das águas e ao tratamento de esgotos. Belo Horizonte, UFMG, 2005, p 243.

VOX, Sandro. Saneamento na Baixada Fluminense. Agência O Dia/Estadão, 01/07/2014. 